\title{
LIETUVOS NACIONALINĖS SVEIKATOS SISTEMOS STACIONARIU ASMENS SVEIKATOS PRIEŽIŪROS İSTAIGŲ SUBORDINAVIMAS IR VEIKLOS KOORDINAVIMAS: EKSTREMALIOSIOS SITUACIJOS REGULIAVIMO YPATUMAI COVID-19 PLITIMO GRĖSMĖS AKIVAIZDOJE
}

\author{
Jelena Kutkauskienè \\ Mykolo Romerio universiteto Teisès mokyklos Viešosios teisès institutas
}

Raktažodžiai: COVID-19 pandemija, sveikatos priežiūros ịstaigos.

\begin{abstract}
Santrauka
Ekstremalios situacijos metu iššūkis efektyviai valdyti situaciją lèmé poreikị keisti ir iš esmès vykdyti teisini reguliavimą. Šiame straipsnyje aptariami sprendimai, kuriais buvo siekiama perorganizuoti stacionarinių asmens sveikatos priežiūros paslaugų teikimą ekstremalios situacijos metu ir analizuojamas priimtų teisès aktų teisinis pagrịstumas.
\end{abstract}

\section{Ivadas}

2019 metais mokslininkai nustate naujają koronovirusų šeimos atmainą, kurią pavadino sunkaus ūminio respiracinio koronoviruso sindromu (angl. severe acute respiratory sindrome coronavirus) (santrumpa SARS-CoV-2 arba COVID-19) (toliau - COVID-19). Šis virusas jau 2019 m. pabaigoje sukèlè ligos protrūkị Uhane (Kinijos Liaudies Respublika), $2020 \mathrm{~m}$. sausio $30 \mathrm{~d}$. Pasaulinè sveikatos organizacija ịvardijo COVID-19 kaip tarptautinès visuomenès sveikatos grèsmę, reikalaujančią neatidèliotinos intervencijos ir jau $2020 \mathrm{~m}$. kovo $11 \mathrm{~d}$. ịvardijo ją pandemija. Visų šalių vykdomoji valdžia susidūre su iššūkiu suvaldyti epidemiologinę situaciją operatyviomis bei efektyviomis priemonèmis, pasitelkiant mokslo patvirtintus metodus. Be ekonominių, socialinių, organizacinių priemonių, ypač reikšmingomis tapo teisinès priemonès, leidžiančios sveikatos sistemai pasirengti naujajam iššūkiui ir neleisti susiklostyti situacijai, kai gydytojams tenka priimti sprendimą, kuriam pacientui bus teikiama pagalba, kaip tai vyko kitose šalyse (pvz., Italijoje, Ispanijoje, Didžiojoje Britanijoje).

Lietuvos Respublikos Vyriausybè (toliau - LRV) $2020 \mathrm{~m}$. vasario 26 d. nutarimu Nr. 152 [1], vadovaudamasi Lietuvos
Respublikos civilinès saugos ịstatymo [2] 9 str. 11 p. ir 26 str. 1 d. 2 p., paskelbè valstybės lygio ekstremaliają situaciją visoje šalyje dèl naujojo koronaviruso (COVID-19) plitimo grèsmès ir sparčiai didejjant sergamumui paveiktose šalyse. Jau 2020 m. kovo 14 d. nutarimu Nr. 207 [3] LRV paskelbė visoje Lietuvos Respublikos teritorijoje karantiną bei nustate jo režimą - apribojimai buvo ịvesti daugelyje visuomenés gyvenimo sričių: asmenų judejjimo per sieną ir šalies viduje, privačiame ir valstybiniame sektoriuose, taip pat ir teikiant sveikatos priežiūros paslaugas.

Iki tol galiojęs teisinis reguliavimas, nustatantis bendruosius civilinès saugos sistemos principus, jos organizacinès parengties užtikrinimą, buvo pakankamas ir nereikalavo skubių intervencijų. Tačiau epidemiologinès situacijos valdymas, susijęs su konkrečiu grèsmę keliančiu virusu - COVID-19, užtikrinant sveikatos sistemos parengti, pareikalavo operatyvaus teisinio reguliavimo. Šiame straipsnyje nagrinejjami Lietuvos nacionalinès sveikatos sistemos (toliau - LNSS), stacionarinių asmens sveikatos priežiūros ịstaigų (toliau ASPI ) veiklos subordinavimo ir koordinavimo reguliavimo pokyčiai ekstremalios situacijos metu.

Šiuo metu nèra daug socialinių mokslų krypties straipsnių, nagrinejjančių ịvairių šalių patirtị suvaldant pandemiją. Daugelis jų skirti suvaldymo priemonių, e.sveikatos paslaugų diegimo galimam poveikiui $[4,6]$ ar asmens apsaugos priemonių (toliau - AAP) [7] reglamentavimo problemoms nagrinèti. Tačiau politikos mokslo specialistai atkreipia dèmesị i pandemijos metu vykdomajai valdžiai tekusi iššūkị suderinti efektyvų valdymą su legitimumu ir skaidrumu [8].

Tyrimo tikslas - atlikti teisès aktų, nustatančių LNSS stacionarinių ASPI veiklos subordinavimo ir koordinavimo reguliavimo pokyčius ekstremalios situacijos metu analizę bei ịvertinti jų teisinị pagrịstumą. 


\section{Tyrimo metodai}

Šiam tikslui pasiekti buvo naudoti sisteminès analizès, loginis, dokumentų analizès metodai.

\section{Tyrimo rezultatai}

Stacionarinių LNSS ASPİ subordinavimą ir veiklos koordinavimą užtikrinančio reguliavimo atitikimo LNSS sąrangos principams ịvertinimas. Pamatinis teisès aktas, numatantis sveikatos sistemos organizacinę parengti COVID-19, yra 2020 m. kovo 4 d. SAM įsakymas Nr. V-281 [9]. Šio įsakymo patvirtintu aprašu visos stacionarinès asmens sveikatos priežiūros įstaigos buvo suskirstytos ị tris kategorijas: 1) pagrindinès ASPI, kuriose infekcinèmis ligomis sergantiems pacientams gydyti skirtas padalinys ir kurių funkcija - diagnostikos ir gydymo paslaugu pacientams, kuriems įtariama ir (ar) diagnozuota COVID-19 liga, teikimas; 2) organizuojanti ASPI yra tretinio lygio stacionarines paslaugas teikianti ASPI nustatytoje veikimo teritorijoje; 3) kitos stacionarinès asmens sveikatos priežiūros ịstaigos organizuoja ASPP teikimą COVID-19 sergantiesiems. Pažymėtina, kad pagrindiné asmens sveikatos priežiūros ịstaigu užduotis yra susijusi su ASPI teikiamų paslaugų nomenklatūra, t.y. su jos profesiniu kvalifikaciniu pajègumu ir pasirengimu teikti reikiamas asmens sveikatos priežiūros paslaugas (toliau - ASPP), o paslaugų teikimą organizuojančių ASPI - su ASPP lygiu. Iki ekstremalios situacijos galiojusių teisès normų, nustatančių stacionarių ASPI funkcijas [12, 44-49 str.], analizė leidžia teigti, kad nei paslaugų lygis, nei jų nomenklatūra nesuteikia ịgaliojimų vienai ASPI organizuoti kitos ASPI veiklos. Todèl šiame kontekste būtina ịvertinti nustatyto teisinio reguliavimo santykị su specialiaisiais sveikatos priežiūrą reglamentuojančiais įstatymais.

LR Sveikatos sistemos įstatymas (toliau - LR SSI) nustato LNSS struktūrą, sveikatinimo veiklos organizavimo ir valstybinio valdymo pagrindus [10]. Minèto įstatymo 12 str. nustato valstybès ir savivaldybių LNSS veiklos organizavimo lygius. Savivaldybės įgyvendina savarankišką funkciją [11, 6 str. 7 p.] - organizuoja pirminę asmens ir visuomenès sveikatos priežiūrą bei ịgyvendina ịstatymo deleguotą valstybès funkciją - organizuoja antrinę asmens sveikatos priežiūrą [11, 7str. 34 p.]. Valstybės lygmens asmens ir visuomenès sveikatos priežiūrą pagal kompetenciją organizuoja SAM ir jai pavaldžios valstybės institucijos LNSS ịstaigose, o išimtinè tretinès asmens sveikatos priežiūros organizavimo teisè suteikta SAM [10, 12 str. 5 d.]. Minèto straipsnio 3 d. visas LNSS priklausančias stacionarines ASPI suskirsto ị lygmenis - rajonų, regionų ir respublikos, tačiau nenustato jų tarpusavio hierarchijos bei nesuteikia valdymo (veiklos organizavimo) kompetencijos. Be to, LR SSI 60-66 str. pateikia baigtini sveikatinimo veiklos valdymo subjektų sąrašą (pvz., LRV, SAM, kitos ministerijos, savivaldybių institucijos) bei visas ASPİ priskiria prie sveikatos priežiūrą vykdomujų subjektų [10, 8 str.], todèl teisès aktu organizuojančioms ASPI suteikta teisè organizuoti jų veiklos zonoje esančiu stacionarinių ASPĮ veiklą, susijusią su COVID-19 sergančiaisiais, duoti jiems privalomus nurodymus, neatitinka minèto reguliavimo.

Stacionarinių LNSS ASPI subordinavimą ir veiklos koordinavimą užtikrinančio reguliavimo priẻmimo pagrindų įvertinimas. Siekiant ịvertinti teisès aktų, nustatančių LNSS stacionarinių ASPI veiklos subordinavimo ir koordinavimo reguliavimo pokyčius ekstremalios situacijos metu teisinị pagrịstumą, būtina išanalizuoti ir įvertinti aprašo preambuleje nurodytus teisès aktus, kuriais grindžiamas jo priemimas.

Pirma, Lietuvos Respublikos sveikatos priežiūros ịstaigu ìstatymo [12] (toliau - LR SPIt) 9 str. 1 d. 3 p., kuris nurodo, kad ịstaigų veiklą nustato ASPP teikimo reikalavimai, patvirtinti SAM įsakymais. Pažymètina, kad tik minèto aprašo baigiamujų nuostatų 19-20 punktai nustato ASPP teikimo reikalavimus, savo turiniu atitinkančius iki pandemijos susiklosčiusią reguliavimo praktiką $[13,14]$. Kitos aprašo nuostatos, nustatančios organizuojančių ASPİ funkcijas, ịpareigoja jas ne tik konsultuoti ir metodiškai vadovauti jų veiklos teritorijoje esančioms ASPI [ $9,9.1$ ir 9.10 punktai] bet ir suteikia plačius igaliojimus organizuojant bei koordinuojant kitu ASPI veiklą [9 ,9.2 p.], kaip antai pacientų srautų valdymas (pacientų nukreipimas ị stacionarinę ASPĮ, sprendimų dèl pacientų perkèlimo ị veikimo teritorijoje esančias ASPI prièmimas ir kt.) [9, 9.3 p.], organizuojančios ASPI veikimo teritorijos ASPP teikimo ir organizavimo planą COVID-19 sergantiesiems (toliau - planas) parengimą. Plane turi būti ASPI užpildymo COVID-19 sergančiaisiais kriterijai, seka, eiliškumas; pacientų srautų (COVID-19 sergančiųų bei kitu pacientų atsižvelgiant i jų patologiją) perskirstymo kriterijai, seka ir etapai; kaip perskirstomas ir (ar) pritraukiamas iš kitų organizuojančios ASPI veikimo teritorijoje esančių ASPI personalas ir jo darbo organizavimo tvarka užtikrinant infekcijų kontrolès reikalavimų laikymąsi; ịpareigojimas operatyviai atnaujinti planą priklausomai nuo epidemiologinès situacijos. Reikia pažymèti, kad organizuojančių ASPI diskrecija organizuoti paslaugų teikimą kitose ASPI apribota šiais infekcijos kontrolę bei racionalų resursų paskirstymą užtikrinančiais principais:

- fizinès infrastruktūros, skirtos teikti ASPP pacientams, kuriems ittariama ar diagnozuota COVID-19 (toliau - COVID-19 pacientai), ir pacientams, sergantiems kitomis ligomis (toliau - ne COVID-19 pacientai), atskyrimas;

- sveikatos priežiūros specialistų ir kito ASPI personalo 
komandų COVID-19 pacientams ir ne COVID-19 pacientams atskyrimas;

- prioritetas teikti AASPP lengva COVID-19 forma sergantiems pacientams;

- kompetencijos - stacionariniam gydymui COVID-19 pacientai hospitalizuojami ị pagrindinę ASPĮ;

- ASPP koncentravimo principas pacientų srautus nukreipiant ị kitas ASPI bei jų reguliavimas atsižvelgiant $\mathfrak{i}$ COVID-19 formą ir eigą;

- infrastruktūros, reikalingos sunkios formos COVID-19 pacientams, plètros kriterijai (pvz., reanimacijos ir intensyvios terapijos lovų skaičiaus padidinimą, pirmiausia jų skaičius turètų būti didinamas pagrindinèse ir (ar) organizuojančiose ASPI);

- COVID-19 pacientų srautų valdymas, priklausomai nuo taikomų gydymo metodų (deguonies terapija, neinvazinè ventiliacija, dirbtinè plaučių ventiliacija bei ilgalaikè dirbtinè plaučiu ventiliacija).

Antra, LR SPII 10 str. 6 p. suteikiančiu SAM teisę nustatyti ASPI tinkamumo ir priimtinumo reikalavimus. Sveikatos priežiūros priimtinumas - tai valstybės nustatyta tvarka pripažįstamos sveikatos priežiūros sąlygos, užtikrinančios ASPP ir medicinos mokslo principų bei medicinos etikos reikalavimų atitiktị [10, 2 str. 32 p.]. ASPP priimtinumo reikalavimais, susijusiais su COVID-19 ligos gydymu, laikytini SAM icsakymais nustatytos rekomendacijos dèl COVID-19 pacientu gydymo [15] bei gausūs soft law šaltiniai (Pasaulinès sveikatos organizacijos (PSO) ir Europos ligu prevencijos ir kontrolès centro (ELPKC), skirtingų profesinių kvalifikacijos gydytojų asociacijų rekomendacijos) [16], kurie apima tiek rekomendacijas dèl gydymo, tiek dèl epidemiologinių sąlygų, siekiant užtikrinti saugų ASPP teikimą COVID-19 pacientams ir ne COVID-19 pacientams. Aprašo nuostatu analizè leidžia teigti, kad jos iš dalies atitinka priimtinumo reikalavimus, kadangi jomis siekiama nustatyti organizacini prieinamumą, kuris atitinka ne medicinos, o visuomenès mokslo pincipų reikalavimus.

Sveikatos priežiūros tinkamumas suprantamas kaip ASPP atitiktis teisès aktų reikalavimams [10,2 str. 35 p.] ir suteikia SAM plačią diskreciją nustatyti reikalavimus paslaugų teikimui, tačiau nesuteikia teisès pavesti vienoms ịstaigoms (šiuo atveju - organizuojančioms ASPI) organizuoti paslaugu teikimą kitose ASPİ.

Trečia, nagrinejjamo SAM ịsakymo prièmimas motyvuojamas LR Žmogaus užkrečiamujų ligų profilaktikos ir kontrolès įstatymo [17] (toliau -LR ŽULPKI ) 8 str., 9 str., 22 str. 2 dalimi ir 26 straipsniu. Šio įstatymo 8 ir 9 str. nustato ligonių, asmenų, itariamų sergančių, turejusių kontaktą, sukèlëjų nešiotojų hospitalizavimo, izoliavimo, ištyrimo ir gydymo, tarp jų ir būtinojo, ypatumus. Tačiau organizuojan- čių ASPI kompetencijos nustatymo prasmé - šios nuostatos nereikšmingos. LR ŽULPKI 22 str. 2 d. ịpareigoja valstybės ir savivaldybių institucijas pagal savo kompetenciją planuoti užkrečiamujjų ligų profilaktikos ir kontrolès organizacines, teisines ir ekonomines priemones ir užtikrinti jų igyvendinimą, o 26 str. detalizuoja valstybès nustatyta savivaldybių institucijų kompetencija valdyti užkrečiamujų ligų profilaktiką ir kontrolę. Šios nuostatos negali būti tiesiogiai siejamos su aprašo prièmimo teisiniu pagrịstumu ar igyvendinimu. Kita vertus, LR ŽULPKI 25 str. 1 d. suteikia SAM kompetenciją vykdyti užkrečiamujjų ligų profilaktikos ir kontrolès valstybinį valdymą, tai yra esant paskelbtai ekstremaliai situacijai Lietuvos Respublikoje, nustatyti tokị teisinị reguliavimą, kuris užtikrintų organizacinių pandemijos valdymo priemonių igyvendinimą. Paminètina, kad ịsakymo leidejjas aprašo prièmimo negrindè šia nuostata. Nepakankamą minimo ịsakymo teisini pagrindimą patvirtina $2020 \mathrm{~m}$. spalio 28 d. SAM sprendimu Nr. V-2408 [18] ittvirtintas ịpareigojimas pagrindinèms ir savivaldybès ligoninėms vykdyti organizuojančių ASPI nurodymus bei savivaldybių administracijoms užtikrinti infrastruktūros pajègumus savivaldybių ASPI̦ pagal organizuojančios ASPI pavedimus.

\section{Išvada}

LNSS stacionarinių ASPI subordinavimą ir veiklos koordinavimą užtikrinantis reguliavimas, kiek suteikia teisę organizuojančioms ASPI duoti privalomus nurodymus kitoms stacionarinèms ASPI , neatitinka bendrujų LNSS sąrangos principų, tačiau ekstremalios situacijos dèl COVID-19 metu gali būti grindžiama Sveikatos apsaugos ministerijos kompetencija vykdyti užkrečiamųjų ligų profilaktikos ir kontrolès valstybinį valdymą.

\section{Literatūra}

1. Lietuvos Respublikos Vyriausybės 2020 m. vasario 26 d. nutarimas Nr. 152 "Dèl valstybès lygio ekstremaliosios situacijos paskelbimo" (TAR, 2020-02-26, Nr. 2020-04023; 2020-06-11, Nr. 2020-12822; 2020-11-04, Nr. 2020-22950).

2. Lietuvos Respublikos civilinės saugos įstatymas (Žin., 1998, Nr. 115-3230; 2009, Nr. 159-7207).

3. Lietuvos Respublikos Vyriausybès 2020 m. kovo 14 d. nutarimas Nr. 207 "Dèl karantino Lietuvos Respublikos teritorijoje paskelbimo" (TAR, 2020-03-14, Nr. 2020-05466)

4. Ohannessian, R., Duong, T. A., \& Odone, A. Global telemedicine implementation and integration within health systems to fight the COVID-19 pandemic: a call to action. JMIR public health and surveillance, 6(2), e18810, 2020.

https://doi.org/10.2196/18810

5. Keesara, S., Jonas, A., \& Schulman, K. Covid-19 and health care's digital revolution. New England Journal of Medicine, 382(23), e82; 2020. 
https://doi.org/10.1056/NEJMp2005835

6. Salvador-Carulla, L., Rosenberg, S., Mendoza, J., TabatabaeiJafari, H., \& Network, P. M. H. I. Rapid response to crisis: Health system lessons from the active period of COVID-19. Health Policy and Technology.2020.

https://doi.org/10.1016/j.hlpt.2020.08.011

8. Christensen, T., \& Lægreid, P. Balancing governance capacity and legitimacy-how the Norwegian government handled the COVID-19 crisis as a high performer. Public Administration Review; Knieps, F. The German healthcare system and the coronavirus pandemic-comments from a legal perspective. Der Urologe. Ausg. A, 59(8), 2020; 919-925.

9. Lietuvos Respublikos sveikatos apsaugos ministro $2020 \mathrm{~m}$. kovo 4 d. įsakymas Nr. V-281 "Dẻl Sveikatos priežiūros paslaugų dèl COVID-19 ligos (koronaviruso infekcijos) organizavimo tvarkos aprašo patvirtinimo" (TAR, 2020-03-04, Nr. 202004862; 2020-04-02, Nr. 2020-06902).

10. Lietuvos Respublikos sveikatos sistemos ịstatymas (Žin., 1994, Nr. 63-1231; 1998, Nr. 112-3099).

11. Lietuvos Respublikos vietos savivaldos įstatymo 6 str. 17 p. (Žin., 1994, Nr. 55-1049; 2000, Nr. 91-2832; 2008, Nr. 1134290).

12. Lietuvos Respublikos sveikatos priežiūros ịstaigų įstatymas (Žin., 1996, Nr. 66-1572; 1997, Nr. 62-1462; 1998, Nr. 1092995).

13. SAM 2020 m. rugpjūčio 31 d. įsakymas Nr. V-1940 "Dėl SAM 2000 m. lapkričio 9 d. ísakymo Nr. 666 "Dél Neurologijos antrinio ir tretinio lygio paslaugų teikimo specialiųjų reikalavimų" pakeitimo" (TAR, 2020-08-31, Nr. 2020-18279).

14. SAM 2007 m. gruodžio 29 d. ịsakymas Nr. V-1085 "Dėl Vidaus ligų profilio paslaugų teikimo specialiųjų reikalavimų patvirtinimo" (Žin., 2008, Nr. 4-145); SAM 2010 m. gruodžio 16 d. įsakymas Nr. V-1073 "Dėl Specialiujų reikalavimų asmens sveikatos priežiūros įstaigos skubiosios medicinos pagalbos skyriui ir skubiosios medicinos pagalbos kabinetui aprašo patvirtinimo" (Žin., 2010, Nr. 148-7636; TAR, 2019-08-26, Nr. 2019-13451).

15. https://SAM .lrv.lt/lt/koronavirusas/informacija-aspi-ir-sveikatos-prieziuros-specialistams-1/koronavirusas-covid-19-irjo-gydymas, (žiūrèta 2020-11-07).

16. https://SAM .lrv.lt/lt/koronavirusas/informacija-aspi-ir-sveikatos-prieziuros-specialistams-1/rekomendacijos-1, [Žiūrèta 2020-11-07].
17. Lietuvos Respublikos žmonių užkrečiamųų ligų profilaktikos ir kontrolès įstatymas (Žin., 1996, Nr. 104-2363; 2001, Nr. 112-4069).

18. Lietuvos Respublikos sveikatos apsaugos ministro $2020 \mathrm{~m}$. spalio 28 d. sprendimas Nr. V-2408 "Dèl pavedimo asmens sveikatos priežiūros paslaugų teikimą organizuojančioms ir šias paslaugas teikiančioms asmens sveikatos priežiūros įstaigoms ir savivaldybių administracijoms vykdymo" (TAR, 2020-10-29, Nr. 2020-22475).

\section{PECULIARITIES OF REGULATION OF SUBORDINATION AND COORDINATION OF HOSPITALS OF THE LITHUANIAN NATIONAL HEALTH SYSTEM IN THE FACE OF THE EMERGENCY SITUATION DUE TO THE THREAT OF COVID-19 SPREAD J.Kutkauskienè}

Keywords: COVID-19 outbreak, health care institutions.

Summary

During an emergency situation, the need to manage the situation effectively led to demand for change and substantially revision of the legal framework. This article discusses the decisions aimed at reorganizing the provision of inpatient health care services during an emergency situation and analyses the substantiality of the adopted legal acts. In this context, the relationship between the established legal regulation and the special laws regulating health care framework and with the legal acts referred to in the preamble, on which its adoption is based, is assessed. The research allows to conclude that the regulation ensuring the subordination and coordination of activities of Lithuanian National Health System hospitals, insofar as it gives the organizing hospitals the right to give mandatory instructions to other hospitals, does not comply with the general rules of the Lithuanian National Health System framework, but can be based on competence of Ministry of Health to execute state-wide managing of the prevention and control of contagious diseases.

Correspondence to: j.kutkauskiene@mruni.eu

Gauta 2020-11-19 